\title{
Gender on the growth of Criollo foals from birth to three years of age
}

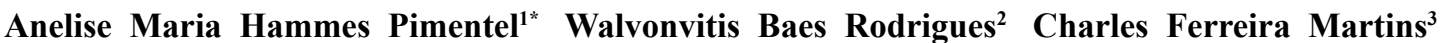 Nathanael Ramos Montanez ${ }^{4}$ Arione Augusti Boligon ${ }^{1}$ João Ricardo Malheiros de Souza ${ }^{5}$}

${ }^{1}$ Departamento de Zootecnia, Faculdade de Agronomia Eliseu Maciel, Universidade Federal de Pelotas (UFPEL), Campus Capão do Leão, 96160-000, Capão do Leão, RS, Brasil. Email: anehammespimentel@gmail.com..'Corresponding author.

${ }^{2}$ Médico Veterinário Autônomo, Campo Grande, MS, Brasil.

${ }^{3}$ Departamento de Clínicas Veterinárias, Faculdade de Medicina Veterinária, Universidade Federal de Pelotas (UFPEL), Pelotas, RS, Brasil. ${ }^{4}$ Curso de Medicina Veterinária, Faculdade de Medicina Veterinária, Universidade Federal de Pelotas (UFPEL), Pelotas, RS, Brasil.

${ }^{5}$ Programa de Pós-graduação em Medicina Veterinária, Centro de Ciências Rurais (CCR), Universidade Federal de Santa Maria (UFSM), Santa Maria, RS, Brasil.

ABSTRACT: The objective of the present study was to evaluate the effect of gender on the growth of Criollo foals, in order to use this information as a reference for breeding as well as in future research. Body height, thoracic perimeter, and cannon bone perimeter of 75 foals were measured from two farms in Rio Grande do Sul, Brazil (Lat. 32 , 33', 58", Long. 53, 22', 33") and from three generations over three years. In both farms, animals were kept under the same range and feeding conditions. Nonlinear regression models were applied to describe the growth curves for the three traits over the experimental period. Cannon bone perimeter was greater in males than in females $(P<0.001)$ but the predicted curves for body height and thoracic perimeter did not differ between genders. For all traits, the highest rate of increase was achieved in the first year of life (body height $=74 \%$, thoracic perimeter $=76 \%$, and cannon bone perimeter $=63 \%$ for males and $83 \%$ for females). Results of this study indicated that changes in body height and thoracic perimeter can be predicted using nonlinear models in both male and female foals, until they reach three years of age; whereas, changes in cannon bone perimeter should be modeled separately for each gender. Key words: horses, growth curve, foal development, morphology, morphometry.

O sexo no crescimento de potros da raça Crioula do nascimento aos três anos de idade

RESUMO: O presente estudo foi desenvolvido com o objetivo de se avaliar o efeito do sexo nos padrões de crescimento em potros da raça Crioula que possam servir de referência à sua criação, assim como base para futuros estudos em equinos dessa raça. Medidas de altura corporal, perímetro de tórax e perímetro de canela de 75 potros, pertencentes a três gerações, foram obtidas do nascimento aos três anos de idade, em duas propriedades no Rio Grande do Sul, Latitude 32 ,33',58" e Longitude 53',22',33". Em ambas as fazendas avaliadas, os animais eram mantidos no mesmo sistema de criação e manejo alimentar (extensivo e em regime de campo nativo). Foram realizadas análises de regressão não linear para se estimar as curvas de crescimento para as três características estudadas. Os resultados do presente estudo indicam diferença significativa $(P<0,001)$ no crescimento da canela entre machos e fêmeas, sendo maior nos machos. As curvas preditas com modelos não lineares para a altura corporal e perímetro de tórax não apresentaram diferenças estatísticas entre os sexos. Para todas as características estudadas, a maior taxa de crescimento foi obtida ao primeiro ano de vida (altura corporal $=74 \%$, perímetro de tórax $=76 \%$ e perímetro de canela $=63 \%$ em machos e $83 \%$ em fêmeas). Os resultados do presente estudo indicam que a evolução da altura corporal e perímetro de tórax em potros até os três anos de idade pode ser avaliada através de modelos não lineares e de maneira simultânea para machos e fêmeas. Por outro lado, o perímetro de canela deve ser modelado separadamente para cada sexo.

Palavras-chave: cavalos, curvas de crescimento, desenvolvimento de potros, morfologia, morfometria.

\section{INTRODUCTION}

From a social and economic point of view, the Criollo breed is considered one of the pillars of the Brazilian equine breeding industry, especially since it generates US $\$ 320,000,000$ every year and $\sim 328,000$ direct and indirect jobs, and it is currently among the three most common horse breeds in Brazil, with over 374,000 registered animals (ABCCC, 2014a). Since conformation plays an important role in domesticating animals-particularly in horsesknowledge of growth curves is key for establishing indexes that can be used in selection processes that will determine breed standards in adult animals.

Breeders aim to produce foals that exhibit optimal growth and development, but determining how to achieve an appropriate growth rate is one of the major concerns. Several researchers have assessed the growth rates of different horse breeds and reported that growth rate is greatest in the first 
year of life (HINTZ et al., 1979; SANTOS et al., 1995; REZENDE et al., 1998). Furthermore, studies have also shown a high incidence of developmental orthopedic diseases (DOD) when foals have a high growth rate (GALIO et al., 2014). Therefore, it is important to establish an ideal growth rate for each breed.

In the Criollo breed, selection is based on conformational and functional performance; however, performance can be affected by growth disorders. Height is a limiting factor in raising Criollo horses for registration reasons. Some animals reach the minimum height requirement for definitive registry by the "Associação Brasileira de Criadores de Cavalos Crioulos" (ABCCC) at the age of 24 months or more; whereas, others achieve heights that approach the maximum limit and have their registry denied, due to concerns that their height will eventually exceed the maximum limit. Thus, the lack of information regarding variability in the development of Criollo foals prevents the use of selective criteria for young animals in the growth phase.

Despite its importance, the Criollo breed has been the focus of relatively few studies, especially with regard to growth and development, issues that are of particular interest to breeders. The present study aimed to assess the effect of gender on the growth standards of Criollo foals, using height, thoracic perimeter, and cannon bone perimeter. The results could potentially serve as a reference for raising Criollo horses, as well as a basis for future studies of the breed.

\section{MATERIALS AND METHODS}

The present study was conducted on two private Criollo farms in the southern region of Brazil, in Jaguarão city, Rio Grande do Sol (Lat. 32 ${ }^{\circ}$, 33', $58^{\prime \prime}$, Long. $53^{\circ}, 22^{\prime}, 33^{\prime \prime}$ ) that both used natural pasture grazing systems, mainly comprising Paspalum notatum, Andropogon lateralis, Coelorachis selloana, and Paspalum dilatatum (PILLAR et al., 2009). The growth of 75 foals from three generations was recorded from birth. Of these, 31 foals from the first generation were measured until they reached 36 months of age. Twenty-two foals from the second generation were measured until they reached 24 months of age, and 22 foals from the third generation were measured until they reached 12 months of age.

Body height, which was defined as the distance from the ground to the highest point of the withers (i.e., the spinous process of the fifth thoracic vertebra), was measured monthly using a ruler marked with centimeters, and both the thoracic perimeter (behind the withers, involving the chest) and cannon bone perimeter (middle third of the metacarpal bone) were measured monthly with the aid of a measuring tape marked with centimeters (Figure 1A). Measurements used in the present study were the same as those used by the ABCCC.

Once the measurements were collected, nonlinear regression analyses were performed, using the mathematical model of RICHARDS (1959) for body height and thoracic perimeter and that of BRODY (1945) for cannon bone perimeter. These models provided the best fit for our data, according to preliminary analysis of various nonlinear regression models for the morphometric characteristics, and are represented by the following expressions:

Brody: $Y=A \times(1-b \times \exp (-k \times t))$

Richards: $Y=A \times\left(1-b \times \exp (-k \times t)^{M}\right.$,

where $A$ is the asymptotic height when age $t$ tends to infinity (i.e., representing the maximum possible value at maturity); $b$ is a constant of integration; $k$ corresponds to the maturity index and determines growth efficiency, thus indicating the rate of maturation; and $M$ determines the shape of the curve, as well as the inflection point (SILVA et al., 2011). To evaluate gender differences, we used the model identity test proposed by RAGAZZI \& SILVA (2004).

\section{RESULTS AND DISCUSSION}

Of the three evaluated traits (Table 1), the only one that differed between genders was cannon bone perimeter (Figure 1B), which was greater in males than in females $(\mathrm{P}<0.01)$. The predicted value in 36-month-old male and female foals was 0.19 and $0.18 \mathrm{~m}$, respectively (Table 2 ), and the equations that best represented the cannon bone perimeter growth in male and females foals, respectively, were:

Males: $\mathrm{Y}=0.1861 \times(1-0.3207 \times \exp (-0.00433 \times$ day)); $\mathrm{P}<0.0001 ; \mathrm{R}^{2}=79.41 \%$

Females: $\mathrm{Y}=0.182 \times(1-0.3304 \times \exp (-0.00484 \times$ day)); $\mathrm{P}<0.0001 ; \mathrm{R}^{2}=83.51 \%$.

For cannon bone perimeter, the overall mean of 18-month-old male foals had already reached the minimum limit necessary for confirmation of the Criollo breed, which is $0.18 \mathrm{~m}$ (ABCCC, 2014b), whereas female foals reached the minimum limit of $0.17 \mathrm{~m}$ for confirmation at 11 months, on average. HINTZ et al. (1979) reported similar differences in cannon bone perimeter between males and females of the Thoroughbred breed, observing that the average cannon bone perimeter at birth was greater for males and the growth curve differentiated from females over time, with the difference accentuated after 


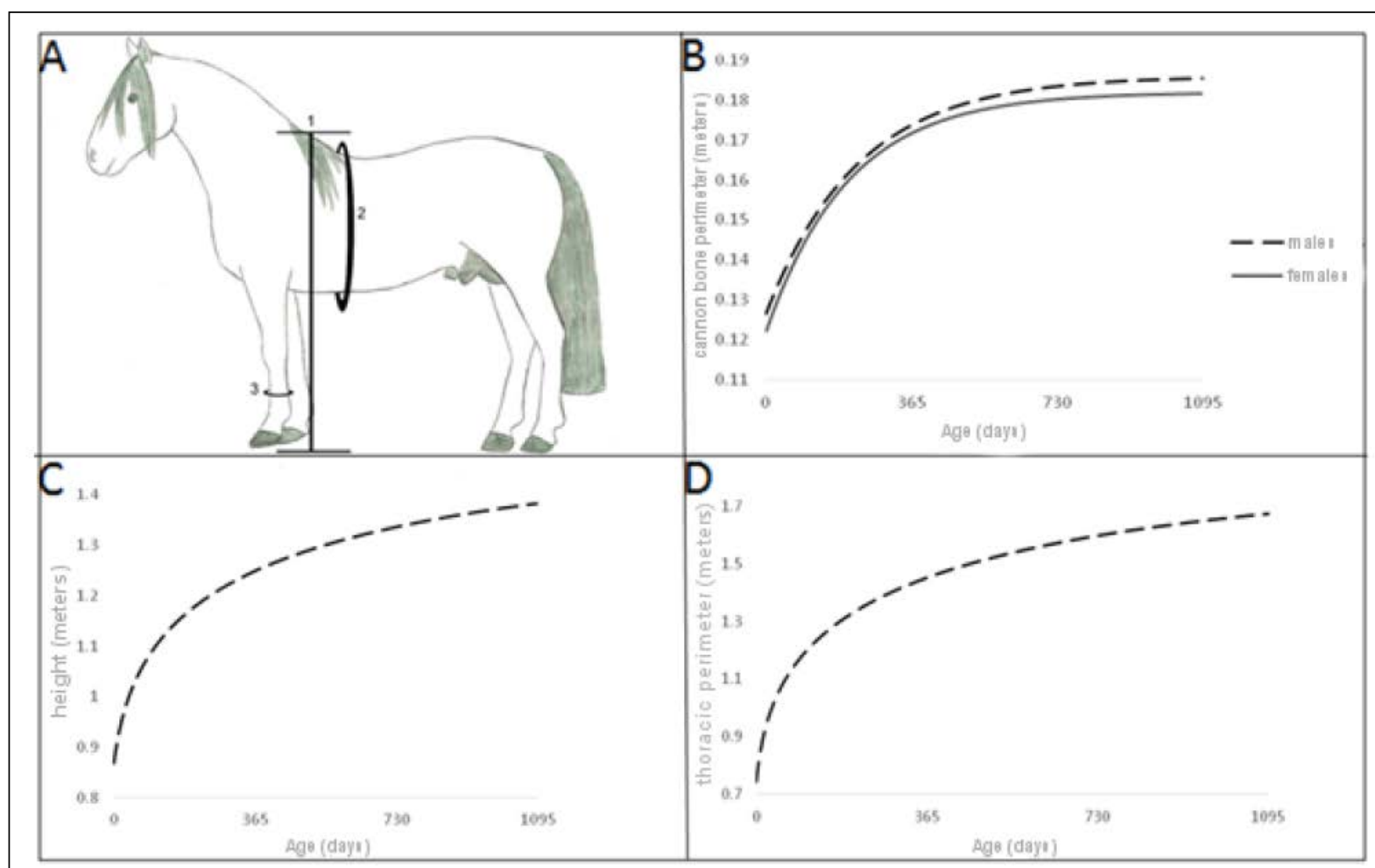

Figure 1 - Growth of Criollo foals from birth until three years of age. A) Dimensions measured in the present study, including body height (1), thoracic perimeter (2), and cannon bone perimeter (3), Image courtesy of Fernanda Streit; B) Growth curve of cannon bone perimeter of male and female Criollo foals from birth to three years of age; C) Growth curve of body height of Criollo foals from birth to three years of age; D) Growth curve of thoracic perimeter of Criollo foals from birth to three years of age.

one year of age. Despite the significant differences observed between males and females in relation to cannon bone perimeter, the differences may be barely noticeable biologically. It should be noted that the models fitted to both genders exhibited very similar asymptote values $(0.186$ and 0.182 for males and females, respectively), which indicated that animals of both genders eventually achieved similar measures of cannon bone perimeter.

For body height, the mean measurements at 12,24 , and 36 months and their percentage in relation to measurements at 36 months are shown in Table 2. The body height of both males and females is represented as a single growth curve, since the two were not significantly different over the tested period $(\mathrm{P}>0.05)$ (Figure 1C).

For body height, the predicted value at 36 months was $1.38 \mathrm{~m}$. This value is close to the mean of $1.37 \mathrm{~m}$ reported by PORTE (2000), using threeyear-old Chilean Criollo horses, but lower than the mean values of 1.42 and $1.41 \mathrm{~m}$ observed by SOUZA et al. (2012) in adult Criollo competitors at the "Freio de Ouro", with ages under and over seven years, respectively. Difference in the heights of foals can be explained, in part, by differences in food management during early growth, since, according to REZENDE et al. (2000), dietary supplementation with feed concentrates and mineral salt (limited to $1.5 \%$ of body weight in Mangalarga Marchador foals) yielded compensatory gains in body height, without the occurrence of flexural deformities members.

The data of our study confirm the findings of SANTOS et al. (1995) and REZENDE et al. (1998) that the body height of foals at birth accounts for about $60 \%$ of their final adult height and that; at 12 months of age, saddle horses have already attained 85 to $90 \%$ of their adult height. Similar values were also observed by MANSO FILHO (1998), using data from Mangalarga Marchador foals, and by SOUZA et al. (1997), using Brasileiro de Hipismo foals, which confirmed the percentage of final height at the withers was $68 \%$ at birth, $86 \%$ at 12 months, and $91 \%$ at 24 months.

At birth, the Criollo foals in the present study averaged $0.87 \mathrm{~m}$ in height, which corresponds to $62.14 \%$ of the minimum height limit stipulated by the ABCCC, which is $1.40 \mathrm{~m}$ for males. At 12 months, they averaged $1.25 \mathrm{~m}(89.28 \%)$; at 24 months, they 
Table 1 - Measurements of Criollo foal dimensions, by gender and age.

\begin{tabular}{|c|c|c|c|}
\hline \multirow{2}{*}{ Trait } & \multirow{2}{*}{ Age } & 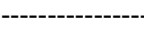 & -------"------"- \\
\hline & & Males & Females \\
\hline \multirow{4}{*}{ Body height (m) } & Birth & $0.94 \pm 0.05$ & $0.93 \pm 0.05$ \\
\hline & 12 months & $1.25 \pm 0.04$ & $1.25 \pm 0.03$ \\
\hline & 24 months & $1.33 \pm 0.05$ & $1.34 \pm 0.03$ \\
\hline & 36 months & - & $1.37 \pm 0.04$ \\
\hline \multirow{4}{*}{ Thoracic perimeter $(\mathrm{m})$} & Birth & $0.90 \pm 0.07$ & $0.90 \pm 0.07$ \\
\hline & 12 months & $1.41 \pm 0.07$ & $1.45 \pm 0.05$ \\
\hline & 24 months & $1.58 \pm 0.07$ & $1.60 \pm 0.06$ \\
\hline & 36 months & - & $1.68 \pm 0.06$ \\
\hline \multirow{4}{*}{ Cannon bone perimeter $(\mathrm{m})$} & Birth & $0.12 \pm 0.01$ & $0.12 \pm 0.01$ \\
\hline & 12 months & $0.17 \pm 0.01$ & $0.17 \pm 0.01$ \\
\hline & 24 months & $0.18 \pm 0.01$ & $0.18 \pm 0.01$ \\
\hline & 36 months & - & $0.18 \pm 0.01$ \\
\hline
\end{tabular}

averaged $1.34 \mathrm{~m}(95.71 \%)$; and at 36 months, they averaged $1.38 \mathrm{~m}(98.57 \%)$. Considering our observed standard deviation of $0.04 \mathrm{~m}$ for the body height of 3 -year-old foals, only animals with heights equal to or greater than half a standard deviation $(0.02 \mathrm{~m})$ above the average could be registered definitively. In other words, about $60 \%$ of the study population had not attained the minimum height for definitive register at 3 years of age. For females, the minimum height limit is $1.38 \mathrm{~m}$, which was achieved at 36 months, on average; however, about $50 \%$ of the foals failed to reach the minimum height. These data are relevant because at this age the animal have to be definitively registered in order to render them eligible to compete. According to PORTE (2000), the desired height can be achieved at three years of age with proper feeding; however, with moderate diet restriction, the animals may not reach their final height until five years of age. Thus, for the foals examined, the animals could be directed to an appropriate food supplementation program before the end of bone growth and permanent commitment of the morphological traits, as also suggested by PINTO et al. (2005).

The results of the present study are also in agreement with those of GREEN (1969), who reported no difference in body height between male and female Thoroughbred foals. In contrast, SANTOS et al. (1992) reported that the body heights of male and female Brasileiro de Hipismo foals were similar at birth but different at 12 months of age, and other studies have reported differences between the heights of male and female Mangalarga Marchador foals from several farms (PINTO et al., 2005), Thoroughbred foals (HINTZ et al., 1979), and Pantaneiro foals maintained on native pastures (SANTOS et al., 2007).

The equation that best represents growth in the Foals' body height from birth until three years of age is:

$\mathrm{Y}=1.4826 \times(1-0.9868 \times \exp (-0.000753 \times \text { day }))^{\wedge}$ $0.124 ; \mathrm{P}<0.0001 ; \mathrm{R}^{2}=89.47 \%$.

There was no significant difference in thoracic perimeter between males and females over the three years evaluated ( $\mathrm{P}>0.05$; Table 2, Figure 1D), and the equation that best explains growth in thoracic perimeter is:

$\mathrm{Y}=1.8148 \times(1-0.9929 \times \exp (-0.000918 \times \text { day }))^{\wedge}$ $0.181 ; \mathrm{P}<0.0001 ; \mathrm{R}^{2}=90.39 \%$.

The predicted thoracic perimeter of the foals was $0.74 \mathrm{~m}$ at birth and $1.67 \mathrm{~m}$ at 36 months. According to the breed standard (ABCCC, 2014b), adult mares must achieve at least $1.70 \mathrm{~m}$ thoracic perimeter and adult males must achieve at least $1.68 \mathrm{~m}$. To determine the thoracic perimeter growth percentage, we used a perimeter of $1.67 \mathrm{~m}$, which 
Table 2 - Predicted values of Criollo foal dimensions at various ages. Percentages represent the accumulated growth in relation to the measurements at 36 months of age, and the growth rate percentages represent the proportion of growth completed in each period in relation to the accumulated growth.

\begin{tabular}{|c|c|c|c|c|c|c|c|c|}
\hline & \multicolumn{4}{|c|}{ 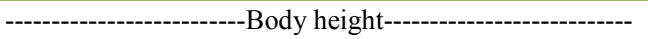 } & \multicolumn{4}{|c|}{ 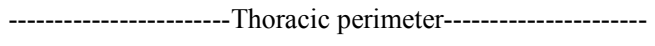 } \\
\hline Age (months) & Predicted value (m) & $\%$ & GR $(\%)$ & $\min / \max$ & Predicted value (m) & $\%$ & GR $(\%)$ & $\min / \max$ \\
\hline Birth & 0.87 & 63.04 & N/A & $0.79 / 0.95$ & 0.74 & 44.31 & $\mathrm{~N} / \mathrm{A}$ & $0.61 / 0.88$ \\
\hline 12 & 1.25 & 90.58 & 74 & $1.17 / 1.32$ & 1.45 & 86.83 & 76 & $1.33 / 1.57$ \\
\hline 24 & 1.34 & 97.1 & 18 & $1.26 / 1.41$ & 1.60 & 95.81 & 16 & $1.47 / 1.72$ \\
\hline \multirow[t]{2}{*}{36} & 1.38 & 100 & 8 & $1.31 / 1.46$ & 1.67 & 100 & 8 & $1.55 / 1.80$ \\
\hline & \multicolumn{4}{|c|}{--------------Cannon bone perimeter - Males------------ } & \multicolumn{4}{|c|}{-------------Cannon bone perimeter - Females----------- } \\
\hline Age (months) & Predicted value (m) & $\%$ & GR $(\%)$ & $\min / \max$ & Predicted value (m) & $\%$ & GR $(\%)$ & $\min / \max$ \\
\hline Birth & 0.13 & 68.42 & $\mathrm{~N} / \mathrm{A}$ & $0.11 / 0.14$ & 0.12 & 66.67 & N/A & $0.11 / 0.14$ \\
\hline 12 & 0.17 & 89.47 & 67 & $0.16 / 0.19$ & 0.17 & 94.44 & 83 & $0.16 / 0.19$ \\
\hline 24 & 0.18 & 94.73 & 17 & $0.17 / 0.20$ & 0.18 & 100 & 17 & $0.17 / 0.19$ \\
\hline 36 & 0.19 & 100 & 17 & $0.17 / 0.20$ & 0.18 & 100 & 0 & $0.17 / 0.20$ \\
\hline
\end{tabular}

GR: growth rate.

was the mean size achieved at 36 months. In the present study, only $40 \%$ of females and $50 \%$ of males reached the desired standard for the variable, taking the deviations into account. However, it is possible that the proportion of animals failing to reach the standard for thoracic perimeter decreases over time, since the model's asymptote estimate is $1.81 \mathrm{~m}$. In addition, although the predicted value for thoracic perimeter was $1.67 \mathrm{~m}$ at 36 months (Table 2), the measurements ranged from $1.55 \mathrm{~m}$ to $1.80 \mathrm{~m}$. The predicted value is close to that observed by PORTE (2000) in Chilean Criollo horses, which exhibited a mean thoracic perimeter measurement of $1.66 \mathrm{~m}$ for males and $1.69 \mathrm{~m}$ for females. However, our observed range differs considerably from the values reported by DOWDALL (1977) for 166 Criollo horses awarded in the Palermo exhibition from 1971 to 1975 , which ranged from 1.71 to $1.94 \mathrm{~m}$ in males and from $1.77 \mathrm{~m}$ to $1.97 \mathrm{~m}$ in females.

From birth to 12 months, the growth rate was higher than $60 \%$ for all variables, and in the yearling period-between the first and the second years of life-the growth rates were all higher than $10 \%$ (Figure 2 ). The growth rate during the first year was at least four times greater than that during the second year. This evidence emphasizes the importance of the quality of care that should be given during this stage of the foals' development. From 24 months to 36 months, all growth rates were lower than $10 \%$, except for that of the cannon bone perimeter of males, which was the same as the rate observed between 12 and 24 months. The cannon bone perimeter in females showed no growth after 24 months.

\section{CONCLUSION}

Results of this study indicated that changes in body height and thoracic perimeter can be predicted using nonlinear models in both male and female foals until they reach three years of age, whereas changes in cannon bone perimeter should be modeled separately for each gender. The predicted model for the studied animals reared under extensive grazing systems showed that about $50 \%$ of individuals failed to achieve the minimum standards for definitive registry at three years of age.

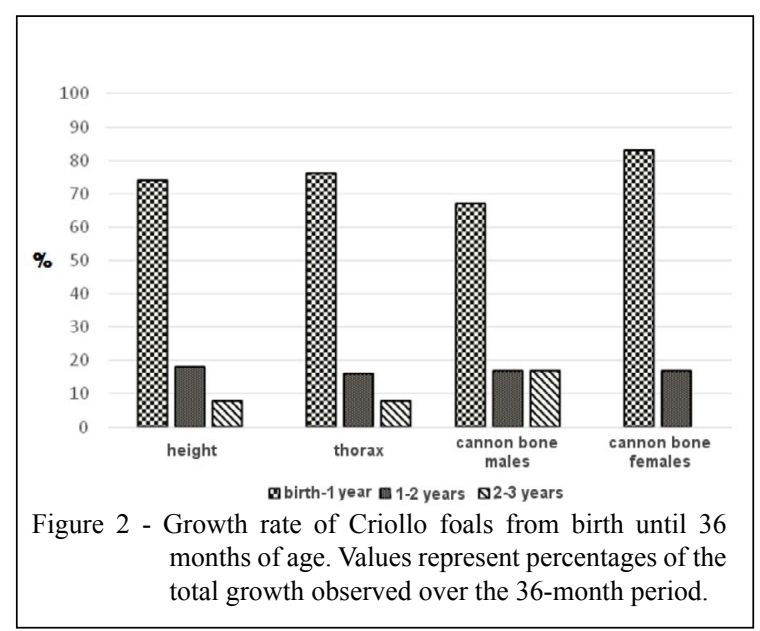




\section{ACKNOWLEDGEMENTS}

The authors thank Dr. João Rouget Perez Wrege (Cabanha Os Charruas) and Dr. Fernando Affonso (in memoriam, Estância Boa Vista) for help during the data collection.

\section{BIOETHICS AND BIOSSECURITY COMMITTEE APPROVAL}

Declaration of the authors:

We, authors of the article entitled "Gender on the growth of Criollo foals from birth to three years of age" declare, for all intents and purposes, that the project that gave origin to the data of the same was not submitted for evaluation to the Ethics Committee of the "Universidade Federal de Pelotas," but we are aware of the content of the resolutions of the O Conselho Nacional de Controle de Experimentação Animal (CONCEA) in Brazil -<http://www.mct.gov.br/index.php/content/view/310553. $\mathrm{html}>$ for studies involving animals. Thus, the authors assume full responsibility for the presented data and are available for possible questioning, if they would be required, by the competent bodies.

\section{REFERENCES}

ABCCC. Anuário da raça Crioula 2014, v.54, n.51, 2014a.

ABCCC. Manual do Criador. Pelotas: Associação Brasileira dos Criadores de Cavalos Crioulos, 2014b. 38p.

BRODY, S. Bioenergetics and growth. New York: Reinhhold Publication, 1945. 1023p.

DOWDALL, Criollos (Uruguay), C.R. Tendências en la seleción de la raza Criolla. Las medidas en Palermo en 1971/75. p.27, 1977.

GALIO, M. et al. Bone changes prevalence in the tarsus of Crioulo yearlings up to 26 months of age. Ciência Rural, Santa Maria, v.44, n.8, p.1442-1447, 2014. Available from: $<$ http://www.scielo.br/scielo. php? script $=$ sci arttext\&pid $=$ S010384782014000801442\&lng $=$ pt $\&$ nrm=iso\&tlng $=$ en $>$. Accessed: Dec. 10, 2014. doi: 10.1590/0103$8478 \mathrm{cr} 20131171$.

GREEN, D.A. A study of growth rate in thoroughbred foals. British Veterinary Journal, v.125, n.10, p.539-546, 1969. Available from: $<$ http://www.ncbi.nlm.nih.gov/pubmed/5394073>. Accessed: Oct. $28,2010$.

HINTZ H.F. et al. Growth rate of thouroughbreds. Effects of age of dam, year and month of birth, and sex of foal. Journal of Animal Science, v.48, p.480-487, 1979. Available from: <http://www.ncbi. nlm.nih.gov/pubmed/575130>. Accessed: Oct. 28, 2014.

MANSO FILHO, H.C. et al. Desenvolvimento corporal de potros da raça Mangalarga- Botucatu, S.P. Marchador durante a fase de amamentação. In: REUNIÃO DA SBZ, 35, 1998, Botucatu. Anais... Botucatu: SBZ, 1998. p.662-664.

PILLAR, V.P. et al. Campos Sulinos - conservação e uso sustentável da biodiversidade. Ministério do Meio Ambiente, Brasília. 2009. 403p. ( p.67-68).
PINTO, L.F.B. et al. Multivariate analysis of body measures in Mangalarga Marchador foals: discriminant analysis. Revista Brasileira de Zootecnia, v.34, n.2, p.600-612, 2005. Available from: <http://www.scielo.br/scielo.php?script=sci arttext\&pid $=\mathrm{S} 1516-35982005000200030>$. Accessed: Oct. 28, 2014. doi: $10.1590 / \mathrm{S} 1516-35982005000200030$.

PORTE, E. Crecimiento e desarrollo del caballo criollo chileno. Avances en Producción Animal, v.25, n.1, p.167-177, 2000.

RAGAZZI, A.J.; SILVA, C.H.O. Teste para verificar a igualdade de parâmetros e a identidade de modelos de regressão não-linear. I. dados no delineamento inteiramente casualizado. Revista Matemática Estatística, v.22, n.3, p.33-45, 2004. Available from: $<$ http://jaguar.fcav.unesp.br/RME/fasciculos/v22/v22_n3/A3_ Adair.pdf>. Accessed: Oct. 28, 2014.

REZENDE, A.S.C. et al. Velocidade de desenvolvimento dos equinos da raça Mangalarga-Marchador. In: REUNIÃO DA SBZ, 35. 1998, Botcatu, SP. Anais... Botucatu: SBZ, 1998. p.273-275.

REZENDE, A.S.C. et al. Effect of two different nutritional programs on orthopedic alterations in Mangalarga Marchador foals. Journal of Equine Veterinary Science, v.20, n.10, p.651-656, 2000.

RICHARDS, F.J. A flexibe growth function for empirical use. Journal of Experimental Botany, v.10, p.290-301, 1959. Available from: <http://jxb.oxfordjournals.org/content/10/2/290. abstract $>$. Accessed: Oct. 28, 2014. doi: 10.1093/jxb/10.2.290.

SANTOS, S.A. et al. Monitoring body development of pantaneiros horses by Growth curves Archivos de Zootecnia. v.56 (Sup. 1), p.647-654, 2007. Available from: <http://www.redalyc.org/ articulo.oa?id=49509948>. Accessed: Oct. 28, 2014.

SANTOS, S.A. et al. Influence of some environmental factors on growth characteristics of brasileiro de hipismo horses to one year of age. Pesquisa Agropecuária Brasileira, v.27, n.1, p.171-179, 1992. Available from: <http://seer.sct.embrapa.br/index.php/pab/ article/view/3632>. Accessed: Oct. 28, 2014.

SANTOS, S.A. et al. Avaliação e conservação do cavalo Pantaneiro. Corumbá-MS: EMBRAPA - CPAP, 1995. p.40. (EMBRAPA-CPAP. Circular Técnica,, n.21).

SILVA, N.A.M. et al. Selection and multivariate classification of nonlinear growth model for Nelore cattle. Arquivo Brasileiro de Medicina Veterinária e Zootecnia, v.63, n.2, p.364-371, 2011. Available from: $<$ http://www.scielo.br/scielo.php?pid=S010209352011000200014\&script $=$ sci_arttext $>$. Accessed: Oct. 28, 2014. doi: 10.1590/S0102-09352011000200014.

SOUZA, J.A.T. et al. Desenvolvimento corporal e estabelecimento da puberdade em potras da raça Brasileira de Hipismo. Revista Brasileira de Reprodução Animal, v.21, n.3, p.117-120, 1997.

SOUZA, J.R.M. et al. Características morfológicas em relação a idade de equinos competidores do freio de ouro. In: CONGRESSO DE INICIAÇÃO CIENTÍFICA, 21., 2012, Pelotas, RS. Anais... Pelotas: Pró-Reitoria de Pesquisa e Pós-Graduação, 2012. Available from: $<$ http://www2.ufpel.edu.br/cic/2012/anais/pdf/CA/CA_01677.pdf>. Accessed: Oct. 28, 2014. 